\title{
Legal Forms and the Practice of Law in Nineteenth-Century Kansas
}

\section{H. Hoeflich*}

Historians depend upon the availability of sources about the subjects upon which they wish to write. At a certain point, there are simply too few sources to permit even a tentative historical narrative. At best, whatever narrative an historian writes will be a partial view of reality as it once was because of the limitations of the sources. ${ }^{1}$ The most common sources utilized by legal historians are the same sources used by practicing lawyers: legislation and court decisions. These form the basis for doctrinal legal history. Within the past fifty years, growing numbers of historians have looked to other sources, such as arrest records, newspaper reports, and other popular media in order to interpret the more traditional sources from a broader perspective. In the past several years, a number of legal historians have expanded their source materials even further by looking at such things as law books and legal publishing, office practices of lawyers, and the places where lawyers practiced. These types of sources are, generally, seen as providing the material with which historians can write about "material culture." In the legal historical context, this refers primarily to the ways in which lawyers practiced law on an everyday basis.

Efforts at writing the history of the material culture of Kansas law have been stymied by a lack of reliable source materials. For the most part, the sources for the everyday life of the law and lawyers in Kansas have either not been preserved or have been scattered in private hands and, thus, are often undiscoverable by historians. ${ }^{2}$ Indeed, in my twenty

\footnotetext{
* John H. and John M. Kane Professor of Law, University of Kansas School of Law.

1. The famous statement by the great German historian Leopold von Ranke, that the historian's duty is to write "what actually happened" (wie es eigentlich gewesen), Leopold von Ranke, The Ideal of Universial History, in VARIETIES OF HiSTORY: FrOM VOLTAIRE TO THE PRESENT 54, 57 (Fritz Stern ed., 2d ed. 1972), is no longer accepted by the historical profession on the grounds that it is simply an impossible task.

2. See Michael H. Hoeflich, Why the History of Kansas Law Has Not Been Written, 26 KAN.
} 
years of writing about Kansas legal history, I have come to realize that the ability to go beyond traditional, doctrinal history requires both a detective-like relentless search in every archive one can find as well as a good dose of luck and serendipity. ${ }^{3}$ This Article arises from just such a serendipitous event.

The early history of the practice of law in Kansas has not been exhaustively studied. Law firm records from this period are virtually impossible to find. The simplest source for understanding law practice is to look to the cases printed in James McCahon's Reports of Cases Determined in the Supreme Court of the Territory of Kansas. ${ }^{4}$ This was the primary source used by the late Paul Wilson in his classic article, "How the Law Came to Kansas." One can also use the docket books of the Territorial District Court now at the Kansas State Historical Society. ${ }^{6}$ For the post-territorial cases, we have Dassler's Reports (also known as Kansas Reports, vol. 1- ). ${ }^{7}$

The problem with all of these sources is that, while they tell us what kinds of cases were litigated in certain Kansas courts and how the courts operated, they do not give us much knowledge of the everyday practice of law in other courts. For this, we need other sources.

Over the past decade, I have attempted to write about the everyday lives and practices of lawyers in early Kansas by looking at such things as the books they owned, the fees that they charged, and the places in which they worked. ${ }^{8}$ In this Article, I wish to use another source for recreating some aspects of the working lives of early Kansas lawyers: the

Hist.: J. Cent. Plains 264, 264-71 (2003), http://www.kshs.org/publicat/history/2003winter_ hoeflich.pdf.

3. See Michael H. Hoeflich, Serendipity in the Stacks, Fortuity in the Archives, 99 L. LiBR. J. 813, 813-827 (2007).

4. James McCahon, Reports of Cases Determined in the Supreme Court of the Territory of Kansas: Together With an Important Case Determined in the District Court of the First Judicial District of Said Territory Before One of the Judges of the Supreme Court and Several Important Cases Determined in the Circuit Court of the United States for the District of Kansas (Chicago, Callaghan \& Cockcroft 1870).

5. Paul E. Wilson, How the Law Came to Kansas, in Musings of a Smiling Bull: SELECTED ESSAYS, ARTICLES AND SPEECHES 77, 77-104 (2000).

6. See M.H. Hoeflich, In Judge Lecompte's Court, 62 U. KAN. L. REv. 1169, 1169-1225 (2014).

7. C.F.W. Dassler was the first State Court Reporter for Kansas. See 3 Frank W. Blackmar, Kansas: A Cyclopedia of State History, Embracing Events, Institutions, Industries, Counties, Cities, Towns, Prominent Persons, Etc. 812-13 (Chicago, Standard Publ'g Co. 1912), https://archive.org/stream/kansascyclopedia32blac\#page/812/mode/1up.

8. See M.H. Hoeflich, Legal Fees in Nineteenth-Century Kansas, 48 U. KAN. L. Rev. 991, 991-1003 (1999) [hereinafter Legal Fees]; Robert A. Mead \& M.H. Hoeflich, Lawyers and Law Books in Nineteenth-Century Kansas, 50 U. KAN. L. REV. 1051, 1051-74 (2002). 
blank legal forms that were published and that the lawyers used to aid them in their practices. My source for this Article is a series of three printed pages pasted into a rather tattered copy of Hugh M. Spalding's Spaulding's Treatise: The Practice and Forms in Justices' Courts for the State of Kansas and an Analysis of the Law and Practice Concerning Personal Property, published by George W. Crane \& Company in Topeka in 1890. ${ }^{9}$ These pages are headed "George W. Crane \& Co.'s Standard Legal Forms" and contain a list of the blank legal forms for sale by Crane, as well as some legal stationary items, that would have been of use to a lawyer practicing in Kansas. From internal evidence, it would appear that there may be one page missing from the full list that was originally published by Crane. ${ }^{10}$

Lawyers are wordsmiths. Much of their work, whether it is office practice or litigation, involves documents. In many cases this work is routine and repetitive. Lawyers in the nineteenth century - as well as their counterparts today-often resorted to the use of preprinted documents with blanks to be filled in with specifics of a transaction or litigation facts in order to work more efficiently. ${ }^{11}$ Efficiency meant increased profit, particularly because most lawyers in the nineteenth century charged by the transaction. ${ }^{12}$ The existence of a list of law blanks published by a Topeka printer gives us a very great insight into the practice of local lawyers at the time because it tells us what type of transactions and court actions were common enough to warrant a publisher to produce the law blanks and to sell them. ${ }^{13}$

9. Hugh M. Spalding, Spalding's Treatise: The Practice and Forms in Justices' COURTS FOR THE STATE OF KANSAS AND AN ANALYSIS OF THE LAW AND PRACTICE CONCERNING ReAl Property (Geo. W. Crane \& Co. eds., 3d ed. 1890). The first edition of this book was published by Crane in 1876. I purchased this source at an estate auction.

10. George W. Crane \& Co.'s Standard Legal Forms (on file with the author) [hereinafter List]. There is a discontinuity on the text between pages 2 and 3 that may indicate a missing page.

11. See M.H. Hoeflich, Law Blanks \& Form Books: A Chapter in the Early History of Document Production, 11 GREEN BAG 2D 189, 189-201 (2008) [hereinafter Law Blanks].

12. On efficiency in nineteenth century law practice, see M.H. Hoeflich, From Scriveners to Typewriters: Document Production in the Nineteenth-Century Law Office, 16 GREEN BAG 2D 395, 398-411 (2013). On transactional billing, see Legal Fees, supra note 8, at 991-92.

13. In essence, publishers do not publish and keep in print materials that do not have a market. To do so would invite financial disaster. See M.H. Hoeflich, Legal Publishing In ANTEBellum AMERICA (2010). Crane was neither the first nor the only Kansas publisher to offer blank legal forms. Many newspapers also published such forms as a source of additional revenue. See Law Blanks, supra note 11, at 195. I have in my personal collection a copy of the General Laws of the State of Kansas (1859), published by the Lawrence Herald of Freedom and once in the possession of E.N.O. Clough and de-accessioned from the University of Kansas Library. On the inside front cover is a printer's ticket that reads: "Herald of Freedom Book Bindery and Blank Book Manufactory, Lawrence, Kansas.” 
We can date the law blank list that I discovered as being published sometime after 1881. That date is derived from evidence internal to the list. On the third page of the list are various blanks designed for the use of township officers. Appended to the end of the list of these is a note that the publisher had enquired of "ex-Attorney-General Davis" on the question "as to whether it was 'proper and legal' for Township Officers to supply Justices of the Peace with form books and law blanks." The Attorney-General in question was Williard Davis who served from January 1877 until January $1881 .^{14}$ Thus, the list must have been published no earlier than 1881. Since it is pasted into a volume published in 1890 , however, it is likely that the list dates from about this year.

Interestingly, Spalding's Treatise has a large collection of legal forms printed alongside the text sections throughout the volume to accompany the text. A good number of these would seem to duplicate the forms listed separately for sale. One might ask why any lawyer would purchase a law blank rather than simply use the forms provided in the book. The answer is, again, cost and efficiency. The cost of the law blanks was very low. The blanks were sold in hundreds and priced by the size of the paper. Thus, a full sheet form was $\$ 3.00$ per hundred. A half sheet blank was $\$ 2.00$ per hundred, a quarter sheet blank was $\$ 1.50$ per hundred, and an eighth sheet blank was $\$ 1.00$ per hundred. ${ }^{15}$ The pricing is in itself interesting because the prices reflect printing and material costs, not the complexity of the forms. ${ }^{16}$ Thus, even the most expensive law blank cost only three cents. This was, presumably, far lower than the cost of the time for the lawyer to copy the form or of having a clerk or scrivener-if the lawyer had a clerk or scrivener-copy the form from the book. ${ }^{17}$ This is simply my opinion based on my experience of the sources.

The list consists of several different categories of forms. The first

14. Kan. Historical Soc'y, Williard Davis, KAN. MEMORY, http://www.kansasmemory.org/ item/215744 (last visited Mar. 6, 2016).

15. List, supra note 10.

16. Some of the forms are significantly more complex than others. To some degree, this may have been taken into account because the pricing depends upon the length of the form assuming more complex forms are longer.

17. Indeed, if clerks were available for copying, they would have been quite expensive for a country lawyer in Kansas. For the costs and complications involved in legal copying during this period, see Law Blanks, supra note 11, at 194-95. See also BELlAMY PARTRIDGE, COUNTRY LAWYER (1939), for an account of how an Eastern rural lawyer used his children as scriveners to save the cost of hiring a professional. 
and largest category of blanks listed are forms for use in the justice courts subdivided into forms for civil and criminal actions. The second major category consists of forms intended for use in the district courts of the state, again divided into civil and criminal. There are also a number of books and forms designed for various state and local officers including trustee record books, clerk's record books, record books for boards of highway commissioners and town auditing boards, and those in charge of cemeteries. There are also forms and books for township officers and road overseers. Also listed are bound docket books for both civil and criminal courts.

An examination of the blanks available for civil actions in the justice courts gives a good picture of the kinds of documents a lawyer practicing in these courts would have had to prepare. There were available, for instance, five blank affidavit forms: the general form, the form for a change of place for trial, the form for a continuance, the form for sureties, and the form for attachment of an account. One can compare this to the text and forms on affidavits found in Spalding. ${ }^{18}$ For instance, Spalding has a section on affidavits in general in which he defines an affidavit:

An affidavit is a statement or declaration reduced to writing and sworn or affirmed to before some officer who has authority to administer an oath.

By general practice, affidavits are allowable to present evidence upon the hearing of a motion, although the motion may involve the very merits of the action; but they are not allowable to present evidence on the trial of an issue raised by the pleadings. Here the witness must be produced before the adverse party. They are generally required on all motions to open defaults or to grant delay in the proceedings and other applications by the defendant addressed to the favor of the court; also, in attachment and garnishment of real and personal effects, replevin of personal property, arrest of the person, forcible entry, etc., which see under their respective titles. ${ }^{19}$

The text then goes on to provide short forms of three versions of a general affidavit. In order to find the form of an affidavit for a change of place of trial, one must go to a different section of the text. In this section, Spalding provides a model form. ${ }^{20}$ Similarly, there is a form and

\footnotetext{
18. SPALDING, supra note 9 , at 117.

19. Id.

20. Id. at 146
} 
explanation of the affidavit for a continuance in another section ${ }^{21}$ and for attachment. $^{22}$

The full range of blanks available for use in the justice courts is quite extensive. A lawyer could obtain blanks in civil actions to use for drawing up an "answer denying account verified," a blank for attaching the property of a delinquent witness, four blanks for depositions, five blanks for undertakings on bonds, six blanks for arrest and bail, seven forms for attachment, eleven blanks for garnishment, a blank for an indemnity bond, three blanks for replevin, two subpoena blanks, four summons blanks, and several various others. ${ }^{23}$ For criminal actions in the justice courts, a lawyer had available a total of twenty-two blanks, including those for complaints, warrants, subpoenas, and even two for bills of costs. ${ }^{24}$

Because the list of blank forms available does not include any text of the forms, it is not possible to know with certainty the extent to which the forms offered for sale were textually the same as those provided by Spalding in his Treatise. However, it seems likely that Crane \& Company would have used much the same language - if not the same language - as that used in Spalding's Treatise ${ }^{25}$ when there was a printed form published corresponding to a blank.

Spalding, of course, is a treatise on practice in Kansas justice courts. The justice courts were the lowest level of general jurisdiction courts in Kansas at the time Spalding was published-jurisdictionally below the district courts and the supreme court. ${ }^{26}$ Justices were elected township officials and had jurisdiction over a large variety of matters - both civil and criminal. ${ }^{27}$ The law blanks available from Crane \& Company reflected the jurisdiction of the justice courts and, as noted, their jurisdiction ran the gamut from depositions to executions of judgment to attachment to garnishment and replevin. These actions would have been part of the general practice of virtually every Kansas attorney of the

21. Id. at 148 .

22. Id. at 384-87. Interestingly, I have not been able to find a form of affidavit for a surety in Spalding although a form of pleading against a surety is found on page 98 .

23. List, supra note 10.

24. Id.

25. It is interesting that the list of forms for sale does not say anything about the author of the forms, which is something that is commonly found in advertisements for blank legal forms during the period. See Law Blanks, supra note 11, at 191-93.

26. See Ruth Y. Wetmore, The Justice of the Peace in Kansas 11-14 (1960).

27. Id. at 14 . 
time. $^{28}$ They were also the least expensive from the point of view of legal fees. For instance, a fee schedule from Douglas County set the fee for attendance at justice court at a minimum of $\$ 25.00$ while the minimum fee for attendance at the district court was $\$ 100 .^{29}$ A similar difference in cost was also found in a Wichita fee schedule of the period. ${ }^{30}$ Thus, it should come as no surprise that the number and variety of legal blanks available for practice in justice courts were more than equal to those available for practice in the district court. ${ }^{31}$ The list of law blanks provides evidence that practice in the justice courts was the "bread and butter" of Kansas lawyers during the last quarter of the nineteenth century.

It is quite easy to understand why lawyers would want to use preprinted forms for justice court practice. As mentioned above, the cost of these law blanks was minimal. On the other hand, fees for most actions in justice court were standardized by the published fee schedules and, for the most part, the fee charged was the minimum stated fee in the schedule. Lawyers would have charged by the hour in only unusual cases. Thus, by keeping the cost of preparing documents to the very low cost of the legal blanks and the labor cost of the lawyer filling in the blank spaces in the preprinted forms, profits per case could be maximized. $^{32}$

The law blanks listed for use in the Kansas district courts very much parallel those for the justice courts with some differences-differences which undoubtedly reflect differences in jurisdiction. For instance, there is a law blank for a "declaration of Intention to become a citizen"something that would not have come within the jurisdiction of the justice courts. ${ }^{33}$ Similarly, there are five forms for actions involving mechanics' liens, two forms for naturalization, and ten forms for foreclosure. As with the blanks intended for justice court practice, these preprinted

28. Since these justice court decisions were not, as a general rule, published in reporters, examination of these law blanks is an important source for understanding the business of these courts and the degree to which lawyers worked in these courts.

29. Legal Fees, supra note 8, at 997.

30. See id. at 999-1000.

31. Much of the practice would have been debt collection, an activity reflected clearly in the availability of relevant forms in the list and corroborated by the number of Kansas lawyers listed in contemporary directories of collection lawyers. See 1884 ATTORNEYs' DiRECTORY OF THE WILBER MERCANTILE AGENCY 61-67 (1884).

32. In effect, the majority of the cost of the action to the lawyer would be his actual time in court. Since a lawyer might well be able to handle a number of cases at the same court session, the fixed fee of $\$ 25.00$ was actually quite generous.

33. See SPALDING, supra note 9, at 25-29, 51, 272-73, 279, 308. 
blanks would have provided a cost efficient tool for Kansas lawyers practicing in the district courts.

The lists also offered a number of stationary items which would have been useful to lawyers and judges. For instance, regular filing envelopes could be purchased for $\$ 1.00$ per hundred as could large-sized envelopes "properly printed for Justices use in filing court papers." ${ }^{34}$ File covers "printed on heavy, smooth manila paper" were also $\$ 1.00$ per hundred. Justices could purchase books of preprinted receipts in twenty-five, fifty, or one hundred receipts per book for $\$ 0.25$ to $\$ 0.75 .{ }^{35}$ Constables could also purchase their own books of receipts for the same amounts. Justices and constables could also purchase notices of fees for ten cents each. Crane notes on the list that justices and constables are required by law to post such notices in their offices and that failure to do so can result in a $\$ 3.00$ per day fine. ${ }^{36}$ One of the most interesting stationary items available for lawyers listed by Crane \& Co. are certificates of admission to the Bar. ${ }^{37}$ According to the list, lawyers had the choice of certificates "lithographed, new and elegant design, on heavy linen ledger paper" at twenty-five cents each or on "genuine parchment" for $\$ 1.00$. One may presume that lawyers were as fond of framing and hanging their Bar admission certificates on the walls of their office at the time this list was published as they are today. ${ }^{38}$

As noted above, in addition to the blank forms available for practice in the justice and district courts, Crane also listed forms for use by town trustees, clerks, treasurers, township officers, highway commissioners, and auditors as well as records for cemeteries. It is not strange that these types of forms were listed along with court forms because many of the lawyers who would have received these forms would also either have served in various official capacities in their communities or would have had clients who did so. Once again, a number of these forms shine some light into the legal affairs of Kansas communities in the latter part of the nineteenth century.

To give an example of these forms, there are listed for sale "trustee's record books." These books, according to the list, included instructions

34. List, supra note 10 .

35. Id.

36. Id.

37. Id.

38. We may also speculate that because few of the lawyers of this period would have had degrees from law schools, the Bar Admission certificate would have been the primary written evidence of their qualification as lawyers. 
on what information was required to be recorded, a preprinted "record of road districts and plat books, record of orders signed, record of township property, poor book, temporary relief, and individual account for services." ${ }^{39}$ One can imagine that such a complete volume including instructions was of enormous value for township trustees without formal legal training. By making such volumes available at low cost (each volume cost $\$ 3.00$ ), a large administrative burden was taken off the shoulders of these community officials and compliance with the various applicable state laws was made easy. ${ }^{40}$

Among the township officer's blanks available for purchase were a number which also give insight into contemporary legal affairs. For instance, one could purchase blank complaints for a tax assessor to use in justice court "when [a] taxpayer refuses to make out [a] statement of personal property." "41 The fact that Crane \& Co. had a market for such forms suggests that noncompliance with personal property tax laws was as much of a problem a century ago is it is today. Another blank was designed for the "overseers of the poor" to use in justice court to have a pauper removed from the official list of the poor. ${ }^{42}$ This, too, indicates that what today is called welfare fraud was a problem a century ago.

The list of law blanks discussed in this Article gives a ground level view of law and governmental practice in Kansas in the latter part of the nineteenth century. It permits us to visualize what a Kansas lawyer would have been doing on a daily basis throughout the state. We can imagine one of our legal forefathers sitting in his office, very likely on the second floor of a city's downtown, ${ }^{43}$ surrounded by stacks of various law blanks and with a few standard books on his shelves: Spalding, Green, Taylor, and the Kansas Reports. ${ }^{44}$ There might also have been a copy of Blackstone's Commentaries on the shelves. ${ }^{45}$ On the walls, one might have found a map of Kansas and, perhaps, the most recent version

\footnotetext{
39. List, supra note 10.

40. Id.

41. Id.

42. $I d$.

43. See Michael H. Hoeflich, The Lawyers of Old Lecompton, in TALLGRASS EsSAYS: PAPERS FROM THE SYMPOSIUM IN HONOR OF DR. RAMON POWERS, 27-35 (2001) (Hoeflich, Davis \& Hoy, eds., 2003).

44. Of course, far more law books were available. See GEORGE W. CRANE \& Co., Brief LAW Catalogue of Geo. W. Crane \& Co. (ca. 1886); Annie L. Diggs, Catalogue of the law BOOKS IN THE KANSAS STATE LIBRARY (1902). However, many if not most practitioners would have owned only a few standard texts and reports. See Mead \& Hoeflich, supra note 8, at 994.

45. See Michael Hoeflich, American Blackstones, in Blackstone AND His Commentaries, 171-84 (Wilfrid Prest ed., 2009).
} 
of the local Bar Association's fee list. ${ }^{46}$ If he had attended a university and a law school, there might even have been a diploma or two, although many Kansas lawyers - even after the University of Kansas and Washburn University established law schools-would have foregone university-based legal education for the more traditional apprenticeship. ${ }^{47}$ These, along with pens, ink, and paper would have been all that was necessary to carry on a law practice. If our hypothetical lawyer had also served in one or more official capacities, he might also have had the appropriate forms and even a record or docket book on his shelves.

This scene I have imagined, is, of course, a far cry from how the law office of today appears - filled with computers, scanners, and other hightech devices. ${ }^{48}$ But it is always good to remember the simple origins of our modern, complex profession and to remember how the practice of law was once carried on. The list of law blanks published by Crane \& Company sometime after 1881 that I was led to by serendipity makes it possible to see this contrast more clearly than would otherwise be possible.

46. See Mead \& Hoeflich, supra note 8, at 996.

47. See Michael H. Hoeflich, Rediscovering Apprenticeship, 61 U. KAN. L. REV. 547, 547-558 (2012).

48. See M.H. Hoeflich \& F. Siler, New Technology \& Lawyer Competency Under Rule 1.1, 85 J. KAN. B. Ass'N (forthcoming 2016). 